\title{
Micro-irrigation development in India: challenges and strategies
}

\author{
A. Suresh* and Manoj P. Samuel
}

In the context of climate change, micro-irrigation (MI; drip and sprinkler systems) has the potential to address problems like water scarcity and emission of greenhouse gases from agriculture. The central and state governments promote MI through heavy subsidies, but without much consideration to supply-side factors like water harvesting, socio-economic factors, including affordability of upfront capital cost and agronomic factors like extant farming system. Despite heavy investments, MI coverage is less than 15\% of the potential. This article contextualizes MI development in India and proposes alternative policies to achieve the twin objectives of water harvesting and its efficient usage. They include developing affordable systems, small farm orientation of technology, popularizing $M I$ in canal commands, prioritization and water budgeting, harnessing circular economy in water usage, and developing institutional mechanisms. MI has the potential to serve both as an adaptation and mitigation strategy against climate change.

Keywords: Climate change, micro-irrigation, water harvesting, greenhouse gases, water-use efficiency.

As a demand-side management strategy, micro-irrigation (MI) has received considerable policy focus in India ${ }^{1,2}$. Promotion of MI is critical to enhance water-use efficiency in the context of rampant extraction of groundwater for irrigation and high variability in rainfall due to climate change. By the year 2030, the demand for food in India is projected to be around 355 million tonnes $(\mathrm{mt})$ for foodgrains, $180 \mathrm{mt}$ for vegetables, $182 \mathrm{mt}$ for milk, $15 \mathrm{mt}$ for meat, and $16 \mathrm{mt}$ for fish, warranting an improvement of $50-100 \%$ over the current production ${ }^{3}$. The strategies to attain this are water-intensive. Further, increased production is to be achieved through reduced emission of greenhouse gases (GHGs) and using cleaner energy. Therefore, development strategies in agriculture need to be centred on regional water availability, water budgeting and its efficient use. This article contextualizes MI development in India, and identifies key strategies to place it as a policy variable for rapid and inclusive agricultural growth.

\section{Structural change in the irrigation sector in India}

The structure of irrigation in India has changed drasticcally $^{4-6}$. Over the years, the area underground-water based minor irrigation has increased sharply over major and medium dam-based irrigation projects. Between 1995-96 and 2010-11, the number of wells in use increased from 8.1 million to 11.4 million (Table 1).

\footnotetext{
A. Suresh and Manoj P. Samuel are in the ICAR-Central Institute of Fisheries Technology, Kochi 682 029, India.

*For correspondence. (e-mail: sureshcswri@gmail.com)
}

The term 'wells' constitutes both dugwells and tube wells (shallow, medium and deep). Tube wells accounts for more than $90 \%$ of the total wells, and contribute to about three-quarter of the total well-irrigated area. Between 1995-96 and 2010-11, the number of tube wells increased from 6.0 million to 7.5 million. As on 2010-11, among the total wells in use, about $88 \%$ were with pump sets and about $45 \%$ of tube wells were electricity-operated.

\section{Climate change and water-use efficiency}

The annual average temperature in South Asia is projected to increase by $1.6^{\circ} \mathrm{C}$ (with a range $1.0^{\circ}-2.3^{\circ} \mathrm{C}$ ) under the climate-sensitive scenario, and $2.2^{\circ} \mathrm{C}$ (range $1.5^{\circ}-3.1^{\circ} \mathrm{C}$ ) under the carbon-intensive scenario by 2050 , relative to 1981-2010 (ref. 7). Agriculture contributes around $20 \%$ of India's net GHG emissions annually ${ }^{8}$. The direct use of diesel and indirect use of electricity in irrigation are major contributors towards this. Under the 'business as usual' scenario, the twin objectives of meeting irrigation water demand with reduced energy footprints cannot be materialized. Hence, the water and energy savings will have to come from improvements in water and energy efficiency. With every $1 \%$ improvement in irrigation efficiency, GHG emissions reduce by $2.1 \%$ (ref. 5).

\section{Savings in water and fertilizer}

The MI, viz. drip and sprinkler, helps targeted application of water to the root zone of the crop, drop by drop as in 
Table 1. Trend in holding size, wells, pump sets and energy sources, 1995-96 to 2010-11

\begin{tabular}{|c|c|c|c|c|c|c|c|c|c|}
\hline \multirow[b]{2}{*}{ Year } & \multirow[b]{2}{*}{$\begin{array}{l}\text { Total holding } \\
\text { ('000) }\end{array}$} & \multirow{2}{*}{$\begin{array}{l}\text { Average } \\
\text { holding } \\
\text { size (ha) }\end{array}$} & \multicolumn{3}{|c|}{ No. of wells in use ('000s) } & \multirow{2}{*}{$\begin{array}{c}\text { No. of } \\
\text { wells not in } \\
\text { use ('000s) }\end{array}$} & \multicolumn{3}{|c|}{ No. of tube wells ('000s) } \\
\hline & & & $\begin{array}{l}\text { With pump } \\
\text { sets }\end{array}$ & $\begin{array}{l}\text { Without } \\
\text { pump sets }\end{array}$ & Total & & $\begin{array}{c}\text { Electricity- } \\
\text { operated }\end{array}$ & $\begin{array}{l}\text { Diesel- } \\
\text { operated }\end{array}$ & Total \\
\hline 1995-96 & 115,580 & 1.41 & 6,710 & 1,401 & 8,111 & 3,159 & 2,989 & 3,059 & 6,048 \\
\hline $2000-01$ & 108,143 & 1.41 & 7,377 & 1,430 & 8,807 & 3,030 & 3,976 & 3,032 & 7,008 \\
\hline 2005-05 & 100,849 & 1.31 & 7,167 & 980 & 8,147 & 2,801 & 4,421 & 3,121 & 7,542 \\
\hline $2010-11$ & 138,348 & 1.15 & 10,100 & 1,316 & 11,416 & 3,083 & 3,425 & 4,067 & 7,492 \\
\hline
\end{tabular}

Source: Compiled from the National Agricultural Censuses, https://agcensus.nic.in/.

the drip system or a spray of tiny droplets on crops akin to rainfall as in the sprinkler system, thereby achieving higher water application efficiency and distribution uniformity. The drip system is suitable for orchard crops like fruits, vegetables and plantation crops, whereas the sprinkler system is more suitable for field crops. MI increases water-use efficiency to the extent of $50-90 \%$ (refs 9, 10).

In 2015-16, India applied about $27 \mathrm{mt}$ of fertilizers on its farms. About 10-20 kg/ha of nitrogen nutrient applied is leached to reach the streams and other water bodies, including groundwater. With a potential savings in fertilizer application along with MI system of $25 \%$, the savings in fertilizer usage and fertilizer subsidy are also significant. The associated benefits of savings in energy and fertilizer reduce cost of cultivation, leading to raised farm income ${ }^{11-13}$. MI also has the potential to bridge the increasing gap between irrigation potential created (IPC) and irrigation potential used, which stands at $22 \%$ of IPC as on 2012 (ref. 6).

\section{Water policy: subsidized electricity and groundwater extraction}

Groundwater development in many states is unsustainable and has crossed $100 \%$, where the annual groundwater usage is far beyond water recharges. Punjab tops the list with a groundwater development of $149 \%$, followed by Rajasthan (140\%; Figure 1). Heavy subsidy on electricity has favoured installation of deep tube wells, disregarding the hydrologic character of the locality ${ }^{14,15}$. Highly subsidized power and water prices have reduced the marginal cost of electricity and water, leading to inefficient usage. The groundwater is applied to the field by flood irrigation method with efficiency less than $40 \%$ (ref. 15). The competitive installation and deepening of bore wells and field application through flooding have led to several social, economic and ecological repercussions ${ }^{16}$.

\section{Micro-irrigation development in India: current status}

MI in India is popularized with a subsidy component, by both the central and state governments. As on 2017, the area covered under MI is about $8.7 \mathrm{~m}$ ha, accounting for only about $13 \%$ of the potential. Maharashtra, Andhra Pradesh, Telangana, Karnataka and Gujarat together account for about $85 \%$ of total drip-irrigated area (Table $2)^{17}$. In case of sprinkler system, Rajasthan and Haryana top the list. Madhya Pradesh, Punjab and Haryana lag far behind compared to their potential. However, groundwater development in these states is more than $100 \%$.

\section{Micro-irrigation schemes}

In 2006, Government of India (GoI) started a centrally sponsored scheme (CSS) for MI. In 2010, CSS was enhanced in scope and renamed as National Mission on Micro Irrigation (NMMI), which was subsequently brought under the ambit of the National Mission on Sustainable Agriculture. In 2015, NMMI was brought as a scheme under the Prime Minister's Krishi Sinchayee Yojana (PMKSY). The scheme envisages providing endto-end solution to irrigation supply chain. The MI development was enhanced through budgetary supports. Union Budget 2017 announced allocation of Rs 7377 crores towards PMKSY. This constitutes an increase of about $42 \%$ over the revised estimates for the fiscal year 201617. About $46 \%$ of this is set aside for the 'per drop more crop' component, which mainly focuses on the development of MI. The government has also proposed to create a MI fund with an initial corpus of Rs 5000 crores, to be mobilized by NABARD through market borrowings. Over and above the subsidy provided by the central government, the states add their share, taking the subsidy component to more than $80 \%$ of the capital costs.

\section{Potential strategies for popularizing micro-irrigation}

\section{Focusing on vulnerable areas and affordable systems}

Prioritization of locations to popularize MI, taking into consideration location-specific demand-supply scenario is warranted. The Central Ground Water Board, New Delhi classifies districts/taluks as safe, semi-critical, critical and over-exploited, depending on groundwater 
GENERAL ARTICLES

Table 2. Spread of micro-irrigation structures across states in India as on 2016

\begin{tabular}{|c|c|c|c|c|}
\hline \multirow[b]{2}{*}{ State } & \multirow[b]{2}{*}{ Area ('000 ha) } & \multirow[b]{2}{*}{ Share to all-India $(\%)$} & \multicolumn{2}{|c|}{ Share to the state $(\%)$} \\
\hline & & & Drip & Sprinkler \\
\hline Andhra Pradesh & 1323.21 & 15.34 & 71.99 & 28.01 \\
\hline Bihar & 107.92 & 1.25 & 9.04 & 90.96 \\
\hline Chhattisgarh & 271.15 & 3.14 & 6.67 & 93.33 \\
\hline Gujarat & 1068.81 & 12.39 & 50.01 & 49.99 \\
\hline Haryana & 576.83 & 6.69 & 4.27 & 95.73 \\
\hline Himachal Pradesh & 7.82 & 0.09 & 54.77 & 45.23 \\
\hline Jharkhand & 20.75 & 0.24 & 52.20 & 47.80 \\
\hline Karnataka & 953.35 & 11.05 & 51.08 & 48.92 \\
\hline Kerala & 30.32 & 0.35 & 75.46 & 24.54 \\
\hline Madhya Pradesh & 430.66 & 4.99 & 52.12 & 47.88 \\
\hline Maharashtra & 1309.67 & 15.18 & 70.59 & 29.41 \\
\hline Odisha & 104.84 & 1.22 & 18.49 & 81.51 \\
\hline Punjab & 47.09 & 0.55 & 73.65 & 26.35 \\
\hline Rajasthan & 1752.67 & 20.32 & 11.62 & 88.38 \\
\hline Sikkim & 9.09 & 0.11 & 66.52 & 33.48 \\
\hline Tamil Nadu & 363.36 & 4.21 & 90.38 & 9.62 \\
\hline Telangana & 94.97 & 1.10 & 79.82 & 20.18 \\
\hline Uttar Pradesh & 42.66 & 0.49 & 39.40 & 60.60 \\
\hline Uttarakhand & 1.01 & 0.01 & 68.77 & 31.23 \\
\hline West Bengal & 51.18 & 0.59 & 1.18 & 98.82 \\
\hline All India & 8626.78 & 100.00 & 45.44 & 54.56 \\
\hline
\end{tabular}

Source: ref. 17 .

Table 3. Trend in the status of blocks/mandals/taluks according to groundwater development, 1995-2013 (\%)

\begin{tabular}{|c|c|c|c|c|c|}
\hline Category & Definition & 1995 & 2004 & 2009 & 2013 \\
\hline Safe $(0-70 \%)$ & Areas which have groundwater potential for development & 92 & 73 & 72 & 69 \\
\hline Semi-critical (70-90\%) & Areas where cautious groundwater development is recommended & 4 & 9 & 10 & 10 \\
\hline Critical $(90-100 \%)$ & Areas which need intensive monitoring and evaluation for groundwater development & 1 & 4 & 4 & 4 \\
\hline Over-exploited (>100\%) & Areas where future groundwater development is linked with water conservation & 3 & 14 & 14 & 16 \\
\hline
\end{tabular}

Source: Central Groundwater Board, http://cgwb.gov.in.

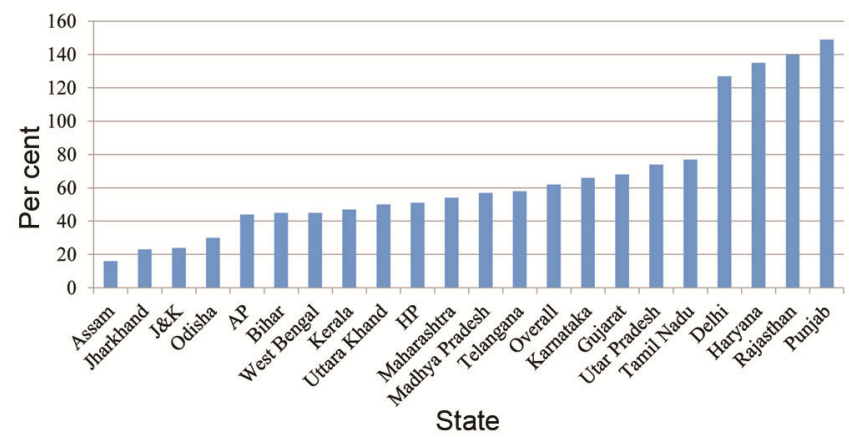

Figure 1. Stage of groundwater development across major states in India in 2013. Source: Central Groundwater Board, New Delhi, http://cgwb.gov.in.

development. The over-exploited districts increased from $3 \%$ in 1995 to $16 \%$ in 2013 , and semi-critical and critical areas together from $5 \%$ to $14 \%$ (Table 3 ). Thus MI needs to focus on areas where unsustainable water extraction is rampant.

The current schemes, which follow direct transfer of subsidy to the producer firms of MI systems, fail to incentivize technology upgradation and cost reduction by instilling competition among producer firms. The technology has to take into account the dominance of small farms (less than $2 \mathrm{ha}$ ) in Indian agriculture and has to reduce the unit cost with add-on technology features so as to hasten the adoption. The experience from Karnataka is a pointer to the importance of reducing the unit cost to popularize the technology ${ }^{18}$.

\section{Popularizing micro-irrigation in canal commands}

Conjunctive use of surface water and groundwater is found to have complementary effect on water productivity and achieving water savings. MI is largely developed in minor irrigation schemes (area irrigated $<2000$ ha). Recent experiences from large irrigation projects also suggest the possibility of integrating MI in canal commands.

The canal commands generally follow flood irrigation system relying on gravity flow. The operational responsibility of dams is with government departments with less 
involvement of beneficiary farmers. Some of the resultant mismatch can be overcome by collecting water in individual or collectively operated water storage structures at the time of release which later can be successfully applied through MI at the proper time. The system is operational in some districts of Gujarat, Karnataka and Rajasthan. Upscaling this technology would require redesigning of irrigation and crop plans in identified areas. Expansion of MI to paddy and sugarcane in canal commands would release much pressure on water demand.

Groundwater being a common property resource, individual farmers try to maximize its extraction. Area expansion of water-intensive crops and consequent overextraction of water jeopardize water conservation objectives. The situation needs appropriate policy targeting limiting water-intensive crops in water-constrained areas. This could be achieved by popularizing MI in canal commands. Basin-wise water budgeting and agricultural plans would help towards this. The extension system needs to consider the issues of water management more emphatically ${ }^{19}$.

\section{Role of renewable energy sources}

The Ministry of Water Resources and Ganga Rejuvenation, GoI, conducts a census on minor irrigation. Currently, preliminary data on the 5 th minor irrigation survey is in public domain. It indicates that the major source of power is electricity (71\%), followed by diesel $(24.8 \%$; Table 4). Between the fourth and fifth minor irrigation census, the number of electricity-operated irrigation systems has increased while those with diesel, manual labour/animal power and 'other sources' has reduced. The share of renewable sources like windmill and solar constitutes only about $0.1 \%$. Solar power-aided pump sets along with MI systems can further reduce the energy requirement and carbon footprints.

\section{Technology development and service provisions}

Irrigation technology is fast changing world over. Sensoraided controllers and automated irrigation systems that can regulate application of water and nutrients are gaining popularity. In view of enhanced saving of water, the policy needs to target add-on features, including precision water management systems. MI is an integral component of precision agriculture technology which has been slowly but steadily gaining popularity, especially for high-value crops. Integration of GIS, GPS and hyper-spectral imaging with precise application of water and fertilizers through the MI system creates a much higher value proposition in the field of high-tech agriculture.

One major constraint faced in MI is the damage that may occur to the pipes and distributaries. Post- installation services like timely and proper maintenance of the drip systems, including filters need to be ensured ${ }^{20}$. Periodic servicing of MI systems by vendors, and encouraging private enterprises/custom-hiring centres is an option.

\section{Circular economy solutions and linking with micro-irrigation}

Circular economy is a model of production and consumption which involves sharing, leasing, reusing, repairing, refurbishing and recycling existing materials and products as long as possible ${ }^{21}$. Circular economy solutions target both the demand- and supply-side management measures in the water sector, for which MI can serve as a useful tool.

In India, out of the estimated sewage generation of 40 60 billion 1/day in urban areas, only $20-30 \%$ is treated. This is in contrast with some technologically advanced countries like Germany and Israel (close to $100 \%$ ), the United States $(75 \%)$, and South Africa $(60 \%)^{22}$. Treated wastewater reuse in Indian agriculture is constrained by policy gaps and ambiguity in tolerance thresholds of toxic chemicals and/or biological organisms. Though the National Water Policy (2012) encourages wastewater reuse to offset the impacts of freshwater extraction, the only standard or policy relevant to governing the application of wastewater in agriculture is the inadequate Central Pollution Control Board standards governing the application of treated agricultural sields ${ }^{23}$. Lack of such standards affects both farmers and consumers alike. Wastewater irrigation through wastewater irrigation cooperatives exists in some districts of Gujarat ${ }^{24}$. The three key factors identified to drive the spread of wastewater irrigation in Gujarat are reliability of water supply, rapid urbanization and profitability of using nutrient-loaded treated water in irrigation. Creation of more distributed infrastructure for wastewater treatment at block levels, establishment of quality and safety benchmarks for treated wastewater for irrigation, awareness building and scientific monitoring of nutrient load by a state-level independent regulator are key to exploring circularity solutions in agricultural water use. Such an arrangement at a large scale needs initiation of pilots at least in major water-constrained districts. Linking MI supports with wastewater recycling initiatives could help attain the objectives of water recycling and its efficient usage.

\section{Financial innovations}

The top-down approach of MI development is fraught with several financial constraints. Further, the minor irrigation distribution in India is inequitable and favours relatively large farmers ${ }^{4}$, which transgresses to the sprinkler and drip irrigation as well. Consequently, much 
Table 4. Change in major sources of power for minor irrigation in India between the fourth and fifth minor irrigation census

\begin{tabular}{|c|c|c|c|c|c|c|c|}
\hline MI Census & Electricity & Diesel & Windmill & Solar & Manual/animal & Others & Total \\
\hline \multicolumn{8}{|c|}{ In numbers ('000) } \\
\hline Fourth & $11,448.4$ & $6,474.5$ & 27.9 & 5.8 & 777.5 & $1,671.6$ & $20,405.6$ \\
\hline Fifth & $14,729.5$ & $5,147.8$ & 29.9 & 16.1 & 281.7 & 557.0 & $20,762.1$ \\
\hline \multicolumn{8}{|c|}{ Percentage to total } \\
\hline Fourth & 56.1 & 31.7 & 0.1 & 0.0 & 3.8 & 8.2 & 100 \\
\hline Fifth & 70.9 & 24.8 & 0.1 & 0.1 & 1.4 & 2.7 & 100 \\
\hline
\end{tabular}

Source: Minor irrigation census, Government of India; http://mowr.gov.in/schemes-projects-programmes/ $\underline{\text { schemes/irrigation-census. }}$

of the subsidy is appropriated by relatively richer farmers. One approach to address larger financial constraints in MI popularization is to follow innovative financial products like hybrid annuity model, which has several advantages over the traditional public-private partnership (PPP) model. Examples of substitution of waterguzzling crops with drip/sprinkler-friendly crops, and pursuing models that offer PPP opportunities (e.g. Ramthal Irrigation project, Karnataka) at a large scale are emerging ${ }^{25}$.

\section{Linking micro-irrigation with water harvesting and conservation initiatives}

The subsidies in MI can be linked with water harvesting initiatives. Rainwater harvesting can be implemented as a viable alternative to conventional water-supply schemes ${ }^{26}$, as noted below.

Run-off interception and recharge: Typically, infrastructure assets required for this intervention depend on the hydro-geomorphology of the watershed and the user characteristics. In arid drylands of India, this offers a low-cost, soft-technology option often adapted by indigenous knowledge, yet producing an optimal return on investments made.

Force infiltration and recharge: This can provide significant gains in increasing resilience of aquifers if coupled with rational groundwater planning and management, coupled with MI. Bhungroo, a water management system that injects and stores excess rainfall underground and lifts it out for use during dry spells, is a rural innovation that has yielded significant gains in water harvesting. The massive underground reservoir can hold as much as 40 million litres of rainwater. It harvests water for about 10 days per year and can supply for as long as seven months ${ }^{27}$.

Linkage of MI with such initiatives in the long term would address supply-side constraints as well.

\section{Enabling institutions and policies for water security}

Managing water resources confronts the issues of managing common property resources. Effective policy-making and institutional governance in water sector become practical when stakeholders with competing interests and demands jointly identify priorities and solve the problems consultatively. Multi-stakeholder/sectoral platforms (MSPs) have produced success stories in several sectors such as renewable energy and agriculture.

MSP models for governance and policy making in agriculture $^{28}$ and water management ${ }^{29}$ have proven success stories from the developing world. MI has to be considered as an integral part of the technology solution considered in the MSP initiative.

\section{Conclusion and implications}

Aided by policy support, groundwater extraction has reached unsustainable proportion in India. MI helps in attaining greater water-use efficiency, thereby reducing the pressure on groundwater sources with reduced GHG emissions. MI has the potential to function both as demand- and supply-side management tool. However, only about $15 \%$ of potential areas could be brought under MI, warranting a course correction.

MI development needs to be seen as an integral component of the overall agricultural policy, rather than a water conservation strategy. There is a need to develop water budgeting for highly localized agricultural units like watersheds, taking into consideration the demand and supply of water, and integrate MI in the crop plans. The command area development programmes need to factor in possibilities of MI development. The targeted geographical locations are to be prioritized, towards which the current stage of groundwater development could function as an indicator.

MI development strategies need to technologically address the concerns of small farms in terms of scale economies, capital constraints and post-installation service requirements. The concept of 'affordable systems' is 
a key element. Ensuring competition among various companies can help in devising irrigation systems with desirable attributes suitable for small farms at lower costs. Water recharge and recycling need to be considered as an integral part of the overall water resource development strategy and linked with the financial schemes promoting MI. Also, MI in canal commands can be promoted through viable PPPs and innovative financial schemes, incentivizing water conservation and recycling. Over a period of time, the subsidy schemes can be reformatted to include incentives to water conservation and water saving. In the context of climate change and water stress, MI programmes could be a worthwhile adaptation and mitigation strategy.

1. Malik, R. P. S., Mark, G. and Rathore, M. S., The negative impact of subsidies on the adoption of drip irrigation in India: evidence from Madhya Pradesh. Int. J. Water Res. Dev., 2016, 34(1), 1-12.

2. Government of India, Budget highlights (key features), 2017; http://indiabudget.nic.in/

3. Indian Council of Agricultural Research. Vision 2030, Ministry of Agriculture and Farmers' Welfare, Government of India, 2011.

4. Suresh, A., Aditya, K. S., Jha, G. and Pal, S., Micro irrigation development in India: an analysis of distributional pattern and potential correlates, Int. J. Water Res. Dev., https://doi.org/10.1080/ $\underline{07900627.2018 .1504755 .}$.

5. Shah, T., Taming the Anarchy: Groundwater Governance in South Asia. Resources for the Future, Washington, DC, and International Water Management Institute, Colombo, Sri Lanka, 2009; https://hdl.handle.net/10568/36566

6. Government of India, Water and related statistics, Water Resource Information Directorate, Central Water Commission, 2015.

7. Mani, M., Bandyopadhyay, S., Chonabayashi, S., Markandya, A. and Mosier, T., South Asia's hotspots: Impact of temperature and precipitation changes on living standards. South Asia Development Matters. World Bank, Washington, DC, 2018; https://openknowledge.worldbank.org/handle/10986/28723

8. Nelson, G. C. et al., Greenhouse gas mitigation - issues for Indian agriculture, International Food Policy Research Institute Discussion Paper, 900, 2009

9. Dhawan, B. D., Technological Change in Indian Irrigated Agriculture: A Study of Water Saving Methods, Commonwealth Publishers, New Delhi, 2002.

10. Saleth, R. M. (ed.), Promoting Irrigation Demand Management in India: Potentials, Problems and Prospects, International Water Management Institute, Colombo, Sri Lanka, 2009.

11. Kumar, S. D. and Palanisami, K., Impact of drip irrigation on farming system: evidence from southern India. Agric. Econ. Res. Rev., 2010, 23, 265-272.

12. Narayanamoorthy, A., Can drip method of irrigation be used to achieve the macro objectives of conservation agriculture? Indian J. Agric. Econ., 2010, 65, 428-440.

13. Pfeiffer, L. and Lin, C. Y. C., Does efficient irrigation technology lead to reduced groundwater extraction? Empirical evidence. J. Environ. Econ. Manage., 2014, 67, 189-208.

14. Kumar, M. D., Groundwater Management in India: Physical, Institutional and Policy Alternatives, Sage Publications, New Delhi, 2007.
15. International Water Management Institute, The Energy-Irrigation Nexus, IWMI, Colombo, Sri Lanka, 2003; http://www.iwmi. cgiar.org/Publications/Water_Policy_Briefs/PDF/web10.pdf

16. Janakarajan, S. and Moench, M., Are wells a potential threat to farmers' well-being? Case of deteriorating groundwater irrigation in Tamil Nadu. Econ. Polit. Wkly., 2006, 77, $3977-$ 3987.

17. Government of India, Agricultural Statistics at a Glance, Directorate of Economics and Statistics, Ministry of Agriculture and Farmers' Welfare, 2017.

18. Global Green Growth Institute implementation roadmap for Karnataka micro irrigation policy, GGGI, Seoul, Republic of Korea, 2015.

19. Sajesh, V. K. and Suresh, A., Public-sector agricultural extension in India: a note. Rev. Agrarian Stud., 2016, 6(1), 116-131.

20. Palanisami, K., Mohan, K., Kakumanu, K. and Raman, S., Spread and economics of micro-irrigation in India: evidence from nine states. Econ. Polit. Wkly., 2011, 46(26\&27).

21. European Parliament, Circular economy: definition, importance and benefits, 2017, pp. 81-86; http://www.europarl.europa.eu/ news/en/headlines/economy/20151201STO05603/circular-economydefinition-importance-and-benefits

22. Marin, P. et al., Water Management in Israel: Key Innovations and Lessons learned for water scarce countries, The World Bank group, 2017; http://documents.worldbank.org/curated/en/ 657531504204943236/pdf/119309-WP-PUBLIC-56p-WcmpeProof. pdf

23. Central Pollution Control Board, Guidelines for water quality management, 2008; http://cpcb.nic.in/openpdffile.php?id= UmVwb3J0RmlsZXMvTmV3SXRlbV85N19ndWlkZWxpbmVzb2Z3YXR1cnF1YWxpdHltYW5hZ2VtZW50LnBkZg==

24. Palrecha, A., Kapoor, D. and Malladi, T., Wastewater irrigation in Gujarat; an exploratory study, IWMI-TATA Water Policy Program, 2012; http://www.iwmi.cgiar.org/iwmi-tata/PDFs/2012 Highlight-30.pdf

25. The Hindu Business Line, Karnataka gets Asia's largest drip irrigation project with Israeli technology, 2018; https://www. thehindubusinessline.com/economy/agri-business/karnataka-getsasias-largest-drip-irrigation-project-with-israeli-tech/article 22592938.ece

26. Samuel, M. P. and Satapathy, K. K., Concerted rainwater harvesting technologies suitable for hilly agrosystems of North East India. Curr. Sci., 2008, 95(9), 1130-1132.

27. UNFCC, Momentum for change: Bhungroo, 2016; https://unfecc. int/climate-action/momentum-for-change/women-for-results/bhungroo

28. Winter, S., Bijker, M. and Carson, M., Multi-stakeholder initiatives: lessons in agriculture. Harvard Kennedy School, Boston, MA, 2017; http://www.technoserve.org/files/downloads/multistakeholder-initiatives-lessons-from-agriculture-report.pdf

29. Jenkins, B., Gilbert, R. and Nelson, J., The 2030 Water resources group: collaboration and country leadership to strengthen water security, Harvard Kennedy School, 2017; https://www.hks. harvard.edu/sites/default/files/2030\%20WRG\%20final.pdf

ACKNOWLEDGEMENT. We thank Mr Ajith Radhakrishnan (World Bank, New Delhi) for critical comments and useful suggestions.

Received 7 February 2019; revised accepted 21 November 2019

doi: $10.18520 / \mathrm{cs} / \mathrm{v} 118 / \mathrm{i} 8 / 1163-1168$ 